\title{
Genetic Polymorphism of ITGA2 C807T Collagen Receptor Encoding Gene of Aspirin Therapy among Javanese-Indonesian Healthy Respondents
}

\author{
Vitarani Dwi Ananda Ningrum ${ }^{1 *}$ (D), Rochmy Istikharah ${ }^{2}$, Ahmad H. Sadewa $^{3}$ \\ ${ }^{1}$ Department of Pharmacy, Laboratory of Pharmaceutical Research, Universitas Islam Indonesia, Yogyakarta, Indonesia; \\ ${ }^{2}$ Department of Pharmacy, Laboratory of Biochemistry, Universitas Islam Indonesia, Yogyakarta, Indonesia; ${ }^{3}$ Department of \\ Biochemistry, Faculty of Medicine, Universitas Gadjah Mada, Yogyakarta, Indonesia
}

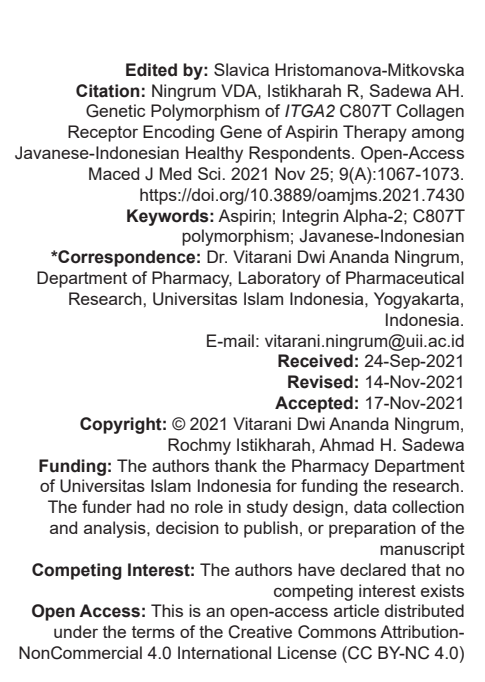

Introduction

As an antiplatelet, aspirin inhibits the cyclooxygenase enzyme, especially the COX-1 isoform which is expressed in a large number of tissues and catalyzes the conversion of arachidonic acid to prostaglandin $\mathrm{G} 2$ and prostaglandin $\mathrm{H} 2$. Then, through the action of thromboxane synthase, these prostaglandins are converted to thromboxane A2 (TXA2), which is a potent activator of platelet aggregation [1]. Therefore, aspirin is able to suppress platelet aggregation with superior affinity for COX1 when compared to COX2, thus causing an antiplatelet effect to occur at a low dose without an anti-inflammatory effect [2]. Despite ample evidence that supports the use of aspirin as both primary and secondary prevention of cardiovascular disease [2], it is estimated that 2-57\% of those taking aspirin show a suboptimal response. Consequently, a number of individuals do not respond to the drug action and experience recurrent vascular thromboembolic events known as aspirin resistance [3].

Clinically, aspirin resistance occurs when aspirin fails to suppress the production of thromboxane A2 and subsequently induces platelet activation and aggregation processes, which increase the risk of death or further cardiac events [4]. A meta-analysis of 20 pieces of research on aspirin resistance shows a nearly 4-fold increase in the risk of further cardiac events and a 6-fold increased risk of death [5]. Some of the factors that lead to the failure of aspirin to suppress TXA2 expression and inhibit platelet aggregation are associated with genetic and non-genetic factors [6]. When patients have been adherent to medication and no other NSAIDs are taken, the genetic factor becomes one of the contributors to the response variability in aspirin administration.

Genetic variation in the form of polymorphism of the integrin alpha-2 (ITGA2) as the glycoprotein la (GPla) encoding gene has proved to change the function 
of aspirin target action as an antiplatelet. Numerous studies focusing on the polymorphism of ITGA2 C807T gene that encodes the GPla collagen receptor have proved its correlation with aspirin resistance. A study of Han Chinese patients with acute ischemic stroke shows that the $\mathrm{T}$ allele significantly correlates with aspirin resistance (OR 4.86) [7]. Similarly, a metaanalysis reveals that rs1126643 (C807T) polymorphism becomes the genetic variation associated with aspirin insensitivity [8], risk of ischemic stroke among the Asian populations [9], and risk of elevated levels of serum cholesterol [10]. In addition, a comprehensive metaanalysis of 60 studies suggests that ITGA2 C807T with the Ser allele of HPA-3 and B allele of glycoprotein Ib $\alpha$ simultaneously correlates with an increased risk of ischemic stroke [11]. Pharmacogenetic research on the pharmacodynamics of aspirin that involves the Indonesian population has never been done to date. Therefore, this study aims to determine the distribution of ITGA2 C807T allele frequency among the Indonesian population, particularly in the Javanese as the major ethnic group in Indonesia.

\section{Materials and Methods}

\section{Research subjects}

This cross-sectional study used the stored biological samples in the form of isolated DNA collected from the $3 \mathrm{ml}$ of blood of 100 healthy subjects of a previous study. The respondents were categorized as Javanese according to their previous three generations of Javanese-Indonesian. This research has passed the ethical review from the Ethics Committee of the Faculty of Medicine of Universitas Islam Indonesia with protocol Number 4/Ka.Kom.Et/D/KE/XII.

\section{Genotype analysis of ITGA2 C807T gene}

Thegenotypeanalysisofthetargetpolymorphism involved the PCR-RFLP method with forward primer 5'-CCTTAAAGCTACCGGCCCATGT-3' and reverse primer 5'-TTGGCCTATTAGCACCAAAACTTACC-3' followed by digestion of the amplicons using the Hpy188I enzyme. The PCR conditions for amplification included pre-denaturation at a temperature of $95^{\circ} \mathrm{C}$ for $2 \mathrm{~min}$, 35 cycles of denaturation at the same temperature for $30 \mathrm{~s}$, annealing at $57^{\circ} \mathrm{C}$ for $30 \mathrm{~s}$, and extension at $72^{\circ} \mathrm{C}$ for $30 \mathrm{~s}$ with the final extension at $72^{\circ} \mathrm{C}$ for $5 \mathrm{~min}$. The visualization of amplification products was prepared using agarose gel electrophoresis with $2.5 \%$ agarose concentration at 70 volts for $90 \mathrm{~min}$. The digestion of $288 \mathrm{bp}$ amplicon resulted in $244 \mathrm{bp}$ and $44 \mathrm{bp}$ fragments of wild-type CC genotype, also $288 \mathrm{bp}$, $244 \mathrm{bp}$, and $44 \mathrm{bp}$ of heterozygous CT genotypes, and $288 \mathrm{bp}$ of mutant TT genotype. The genotype and allele frequencies were determined based on the Hardy-Weinberg principle as follows [12], [13]

$$
\begin{gathered}
\begin{array}{c}
\text { Number of individuals with a } \\
\text { specific genotype }
\end{array} \\
\text { Total number of individuals }
\end{gathered}
$$

$$
(2 \times \text { Number of CC Individuals })
$$

C Allele frequency $=\frac{+(\text { Number of CT Individuals })}{(2 \times \text { Total Number of Individuals })}$

$(2 \times$ Number of TT Individuals $)$

T Allele frequency $=\frac{+(\text { Number of CT Individuals })}{(2 \times \text { Total Number of Individuals })}$

\section{Results}

There were 100 healthy respondents from Javanese-Indonesian ethnic group involved in this study of the SNPs frequency of ITGA2 rs1126643 C>T gene, consisting of men and women in equal number. The characteristics of the research subjects are presented in Table 1.

Table 1: Characteristics of the research subjects

\begin{tabular}{lll}
\hline Patient characteristic & Male $(\mathrm{n}=50)$ & Female $(\mathrm{n}=50)$ \\
\hline Mean age $($ years $)$ & $21.26 \pm 1.21$ & $21.14 \pm 1.43$ \\
Mean BMI $\left(\mathrm{kg} / \mathrm{m}^{2}\right)$ & $22.73 \pm 4.09$ & $21.49 \pm 3.41$ \\
Type of $I T G A 2 \mathrm{rs} 1126643$ C $>$ T genotype & \\
CC & 19 & 22 \\
CT & 28 & 23 \\
TT & 3 & 5 \\
Type of ITGA2 rs1126643 C>T allele & & \\
C & 0.66 & 0.67 \\
T & 0.34 & 0.33 \\
\hline BMI: Body mass index. & &
\end{tabular}

The subject characteristics in terms of both phenotypic factor, which includes mean age and BMI, and genotypic factor related to genetic variants in the target SNPs indicate no significant differences between men and women ( $p>0.05)$. Overall, this study found that the majority of genotypic variants in the ITGA2 rs1126643 C>T gene were CT type and C allele. Figure 1 shows the electrophoretic display of the enzyme digestion products for detecting the target polymorphism.

\section{Discussion}

The frequency of genotypic variants in ITGA2 C807T as the GPla protein-encoding gene does not significantly differ between the men and the women in this study. In contrast to the GPIlb-IIla receptors, the GPla collagen receptor shows no different expression based on sex [14]. However, differences 


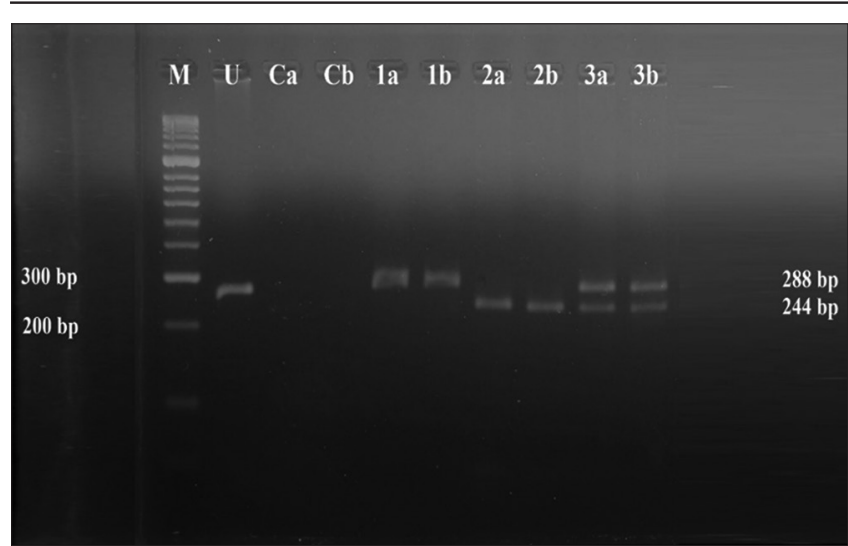

Figure 1: Visualization of Hpy188/ digestion products. Lane $M=50 \mathrm{bp}$ marker/ladder; lane $U=$ undigested product/PCR product; lane C. $a$ and C. $b=$ negative control; lane $1 a$ and $1 b=$ subjects with $T T$ genotype; lane $2 a$ and $2 b=$ samples with mutant (CC genotype); lane $3 a$ and $3 b=$ sample with heterozygote (CT genotype)

in the response to aspirin as primary cardioprotection between men and women have been discussed by a gender-specific meta-analysis [15]. Similarly, the WHI long-term study has found aspirin to be effective for primary prevention of stroke in female patients but ineffective for that of myocardial infarction (MI). In contrast, aspirin is effective as a primary prevention of $\mathrm{MI}$ in men. However, there is no clarity as to what causes such differences, making it necessary to probe for further explanation [16]. In addition, in conjunction with clinical studies that involve only a small number of female subjects, especially in Phase 1 , and recent findings other than pharmacokinetic studies, genderrelated differences have proved to influence the pharmacodynamics and pharmacogenomics of drugs, including aspirin. Consequently, before such studies are translated into a clinical setting, a gender-based approach is required to draw a feasible conclusion for both genders so as to adjust the administration of aspirin according to individual needs [17]. If further studies can provide evidence to reinforce the presence of significant differences in the pharmacokinetics and pharmacodynamics of aspirin between the two genders, then the pharmacogenomic studies of aspirin, in addition to the study designs that involve a control group and adequate sample size, are required to employ equal proportion of both genders to provide more accurate data analysis and results.

A number of studies with the same SNPs targets as this study and with the pharmacodynamic impacts of aspirin have been carried out among various populations (Table 2).

Table 2 describes the studies published as original articles with the majority of them finding no correlations between ITGA2 C807T and an increased

Table 2: Genotype frequencies of GP1a C807T in various populations in the world

\begin{tabular}{|c|c|c|c|c|c|c|}
\hline \multirow{2}{*}{$\begin{array}{l}\text { Population/ } \\
\text { Race }\end{array}$} & \multirow[t]{2}{*}{ Number of samples } & \multicolumn{3}{|l|}{ Genotype frequency (\%) } & \multirow[t]{2}{*}{ Finding } & \multirow[t]{2}{*}{ References } \\
\hline & & $\mathrm{CC}$ & CT & TT & & \\
\hline $\begin{array}{l}\text { Original article } \\
\text { Javanese, } \\
\text { Indonesia }\end{array}$ & 100 & 41.0 & 51.0 & 8.0 & $\begin{array}{l}\text { The frequency of GP1a C807T } \\
\text { mutant allele was lower than that } \\
\text { of C allele }\end{array}$ & Present study \\
\hline Caucasian & $\begin{array}{l}2369 \text { patients with VTE, } 1460 \text { healthy } \\
\text { subjects }\end{array}$ & Case 34.6 Control 36.0 & $\begin{array}{l}\text { Case } 48.1 \text { Control } \\
46.7\end{array}$ & $\begin{array}{l}\text { Case } 17.3 \text { Control } \\
17.3\end{array}$ & $\begin{array}{l}\text { There was no difference in } \\
\text { the frequency of GP1a C807T } \\
\text { polymorphism between VTE } \\
\text { and the control, but there was } \\
\text { a significantly increasing risk } \\
\text { among } 732 \text { VTE patients with } \\
\text { a family history of myocardial } \\
\text { infarction and/or stroke }\end{array}$ & $\begin{array}{l}\text { Kvasnicka et al. } \\
(2015)[18]\end{array}$ \\
\hline Han Chinese & $\begin{array}{l}503 \text { patients with ST-elevation myocardial } \\
\text { infarction }\end{array}$ & Data not shown & & & $\begin{array}{l}\text { There was no association } \\
\text { between ITGA2 C } 807 T \\
\text { polymorphism in the platelet } \\
\text { receptor encoding gene and } \\
\text { the risk of ischemic stroke and } \\
\text { bleeding incidence }\end{array}$ & $\begin{array}{l}\text { Zhang et al. (2016) } \\
\text { [19] }\end{array}$ \\
\hline Jordanian & 584 patients & $\begin{array}{l}\text { Aspirin responders } 38.4 \\
\text { Aspirin non-responders } \\
43.5\end{array}$ & $\begin{array}{l}\text { Aspirin responders } \\
47.2 \\
\text { Aspirin } \\
\text { non-responders } \\
50.0\end{array}$ & $\begin{array}{l}\text { Aspirin } \\
\text { responders } 14.4 \\
\text { Aspirin } \\
\text { non-responders } \\
6.5\end{array}$ & $\begin{array}{l}\text { The GP1a C807T polymorphism } \\
\text { was not associated with aspirin } \\
\text { resistance }\end{array}$ & $\begin{array}{l}\text { Al-Azzam et al. } \\
\text { (2013) [20] }\end{array}$ \\
\hline Ukrainian & $\begin{array}{l}54 \text { patients with stable angina pectoris II-III } \\
\text { and ACS with history of } \mathrm{PCl}\end{array}$ & $\begin{array}{l}\text { Aspirin responders } 63.2 \\
\text { Aspirin non-responders } \\
17.1\end{array}$ & $\begin{array}{l}\text { Aspirin responders } \\
21.0 \\
\text { Aspirin } \\
\text { non-responders } \\
25.7\end{array}$ & $\begin{array}{l}\text { Aspirin } \\
\text { responders } 15.8 \\
\text { Aspirin } \\
\text { non-responders } \\
53.2\end{array}$ & $\begin{array}{l}\text { Declined sensitivity to aspirin as } \\
\text { an antiplatelet was correlated with } \\
\text { ITGA2 C807T polymorphism in } \\
\text { patients with ACS after PCI. IHD } \\
\text { patients with T allele had a lower } \\
\text { platelet response especially in } \\
\text { patients who received antiplatelet } \\
\text { therapy, including aspirin }\end{array}$ & $\begin{array}{l}\text { Liakhotska (2017) } \\
\text { [21] }\end{array}$ \\
\hline Caucasian & 179 stroke patients, 172 control & $\begin{array}{l}\text { Stroke with } 3 \text { subtypes } \\
44.1 \text { Control } 34.3\end{array}$ & $\begin{array}{l}\text { Stroke with } 3 \text { subtyp } \\
\text { Control } 65.7\end{array}$ & pes (CT/TT) 55.9 & $\begin{array}{l}\text { The integrin } \alpha 2 \text { C } 807 \mathrm{~T} \\
\text { polymorphism did not affect the } \\
\text { development of ischemic stroke }\end{array}$ & $\begin{array}{l}\text { Cole et al. (2003) } \\
\text { [22] }\end{array}$ \\
\hline German & 941 patients with stable CAD & 40.4 & 43.6 & 16.0 & $\begin{array}{l}\text { Together with rs } 1062535 \text { SNPs, } \\
\text { rs } 1126643 \text { polymorphism was } \\
\text { associated with the prognosis } \\
\text { of cardiovascular diseases, } \\
\text { especially in high-risk patients }\end{array}$ & $\begin{array}{l}\text { Rath et al. (2017) } \\
\text { [23] }\end{array}$ \\
\hline
\end{tabular}


Table 2: (Continued)

\begin{tabular}{|c|c|c|c|c|c|c|}
\hline \multirow{2}{*}{$\begin{array}{l}\text { Population/ } \\
\text { Race }\end{array}$} & \multirow[t]{2}{*}{ Number of samples } & \multicolumn{3}{|l|}{ Genotype frequency (\%) } & \multirow[t]{2}{*}{ Finding } & \multirow[t]{2}{*}{ References } \\
\hline & & $\mathrm{CC}$ & CT & TT & & \\
\hline Caucasian & $\begin{array}{l}286 \text { healthy subjects, } 160 \text { patients with } \\
\text { hereditary mucocutaneous bleeding }\end{array}$ & Data not shown & $\begin{array}{l}\text { CT+TT Patients witl } \\
\text { Control } 65.6\end{array}$ & h bleeding 67.1 & $\begin{array}{l}\text { The ITGA2 C807T polymorphism } \\
\text { did not significantly influence the } \\
\text { platelet function and not correlate } \\
\text { with the pathogenesis of bleeding } \\
\text { incidence }\end{array}$ & $\begin{array}{l}\text { Martinez et al. } \\
\text { (2009) [24] }\end{array}$ \\
\hline Chinese & $\begin{array}{l}350 \text { patients with ischemic stroke patients } \\
300 \text { control }\end{array}$ & Patients 42.3 Control 46.3 & $\begin{array}{l}\text { Patients } 39.4 \\
\text { Control } 45.3\end{array}$ & $\begin{array}{l}\text { Patients } 18.3 \\
\text { Control } 8.3\end{array}$ & $\begin{array}{l}\text { The ITGA2 C807T polymorphism } \\
\text { affected ischemic stroke with the } \\
\text { T allele apparently playing a role } \\
\text { in increasing the cholesterol levels }\end{array}$ & Lu et al. (2014) [10] \\
\hline Dutch & $\begin{array}{l}1327 \text { patients with primary } \mathrm{PCI} \text { who } \\
\text { received aspirin-clopidogrel combination } \\
\text { therapy }\end{array}$ & $\begin{array}{l}\text { Group with primary event } \\
(n=86) 45.3 \text { Group without } \\
\text { primary event }(n=1241) \\
34.3\end{array}$ & $\begin{array}{l}\text { Group with } \\
\text { primary event } 37.2 \\
\text { Group without } \\
\text { primary event } 51.1\end{array}$ & $\begin{array}{l}\text { Group with } \\
\text { primary event } \\
17.5 \text { Group } \\
\text { without primary } \\
\text { event } 13.6\end{array}$ & $\begin{array}{l}\text { Thrombotic complications during } \\
\text { the follow-up, in the form of } \\
\text { cardiac death or recurrent attacks } \\
\text { of myocardial infarction, were not } \\
\text { associated with ITGA2 C807T } \\
\text { polymorphism }\end{array}$ & $\begin{array}{l}\text { Verchuren et al. } \\
\text { (2013) [25] }\end{array}$ \\
\hline Chinese & $\begin{array}{l}1544 \text { patients (cohort } 2 \text { ) who received } \\
\text { CABG (Coronary Artery Bypass Graft) and } \\
\text { follow-up for } 72.8 \text { years } \\
\text { Major adverse cardiovascular or } \\
\text { cerebrovascular events were confirmed } \\
\text { by a previous cohort study involving } 646 \\
\text { patients (cohort } 1 \text { ) with CABG } \\
\text { For mechanism tracking, } 131 \text { CAD patients } \\
\text { were tested for the function of platelet } \\
\text { aggregation, GP1a mRNA, and protein } \\
\text { expression }\end{array}$ & $\begin{array}{l}\text { Cohort } 1 \\
\text { Case } 18.8 \\
\text { Control } 81.2 \\
\text { Cohort } 2 \\
\text { Case } 9.2 \\
\text { Control } 90.8\end{array}$ & $\begin{array}{l}\text { Cohort } 1 \\
\text { Case } 23.4 \\
\text { Control } 76.6 \\
\text { Cohort } 2 \\
\text { Case } 15.3 \\
\text { Control } 84.7\end{array}$ & & $\begin{array}{l}\text { The GPla rs } 1126643 \\
\text { polymorphism increased the } \\
\text { risk of CABG adverse events } \\
\text { through increasing GPla protein } \\
\text { expression and increasing } \\
\text { function of platelet aggregation }\end{array}$ & Liu et al. (2016) [26] \\
\hline Czech & $\begin{array}{l}73 \text { patients with acute or chronic IHD } \\
\text { who experienced bleeding complications } \\
\text { within } 30 \text { days after cardiac catheterization } \\
\text { (CAG) or } \mathrm{PCI}, 331 \text { patients without } \\
\text { bleeding as the control }\end{array}$ & Total (404) 43.3 & 44.3 & 12.4 & $\begin{array}{l}\text { There was no significant } \\
\text { association between haplotype } \\
4 \text { SNPs, including GP1a } \\
\text { C807T, and increased risk of } \\
\text { periprocedural bleeding in IHD } \\
\text { patients who had CAG/PCl }\end{array}$ & $\begin{array}{l}\text { Sionova et al. (2017) } \\
\text { [27] }\end{array}$ \\
\hline Pakistani & $\begin{array}{l}\text { Patients who received aspirin, } 23 \\
\text { non-responders (case), } 60 \text { responders } \\
\text { (control) }\end{array}$ & $\begin{array}{l}\text { Aspirin responders } 40.0 \\
\text { Aspirin } \\
\text { non-responders } 35.0\end{array}$ & $\begin{array}{l}\text { Aspirin responders } \\
37.0 \\
\text { Aspirin } \\
\text { non-responders } \\
39.0\end{array}$ & $\begin{array}{l}\text { Aspirin } \\
\text { responders } 23.0 \\
\text { Aspirin } \\
\text { non-responders } \\
26.0\end{array}$ & $\begin{array}{l}\text { There was no significant } \\
\text { difference in the genotype and } \\
\text { allele frequencies of GPIA C807T } \\
\text { polymorphism between the } \\
\text { aspirin non-responders group and } \\
\text { responders group }\end{array}$ & $\begin{array}{l}\text { Mukarram et al. } \\
\text { (2016) [28] }\end{array}$ \\
\hline Han Chinese & $\begin{array}{l}97 \text { patients with acute ischemic stroke; } \\
\text { aspirin sensitivity (AS) group with } 54 \\
\text { subjects, } \\
\text { aspirin resistance (AR) group with } 43 \\
\text { subjects }\end{array}$ & $\begin{array}{l}\text { AS } \\
42.6 \\
\text { AR } \\
27.9\end{array}$ & $\begin{array}{l}\text { AS } \\
48.1 \\
\text { AR } \\
53.5\end{array}$ & $\begin{array}{l}\text { AS } \\
9.3 \\
\text { AR } \\
18.6\end{array}$ & $\begin{array}{l}\text { The SNPs of GPla C807T gene } \\
\text { were correlated with aspirin } \\
\text { resistance in Han Chinese } \\
\text { women }\end{array}$ & $\begin{array}{l}\text { Wang et al. (2018) } \\
\text { [7] }\end{array}$ \\
\hline Japanese & 110 healthy subjects & 39.1 & 47.3 & 13.6 & $\begin{array}{l}\text { The GPIA C807T polymorphism } \\
\text { was not involved in the laboratory } \\
\text { aspirin resistance according to the } \\
\text { platelet aggregation parameter }\end{array}$ & $\begin{array}{l}\text { Fujiwara et al. } \\
\text { (2007) [29] }\end{array}$ \\
\hline Chinese & $\begin{array}{l}307 \text { patients with gastric cancer (case), } \\
307 \text { control }\end{array}$ & $\begin{array}{l}\text { Case } \\
45.9 \\
\text { Control } \\
55.4\end{array}$ & $\begin{array}{l}\text { Case } \\
44.0 \\
\text { Control } \\
36.8\end{array}$ & $\begin{array}{l}\text { Case } \\
10.1 \\
\text { Control } \\
7.8\end{array}$ & $\begin{array}{l}\text { The subjects with }(\mathrm{CT}+\mathrm{TT}) \\
\text { variants had a significantly higher } \\
\text { risk of gastric cancer }\end{array}$ & $\begin{array}{l}\text { Chen et al. (2011) } \\
\text { [30] }\end{array}$ \\
\hline Caucasian & $\begin{array}{l}118 \text { patients with idiopathic sudden } \\
\text { sensorineural hearing loss (iSSNHL), } \\
161 \text { control }\end{array}$ & $\begin{array}{l}\text { Patients with iSSNHL } \\
35.6 \\
\text { Control } \\
52.2\end{array}$ & $\begin{array}{l}\text { Patients with } \\
\text { iSSNHL } \\
52.5 \\
\text { Control } \\
40.4\end{array}$ & $\begin{array}{l}\text { Patients with } \\
\text { iSSNHL } \\
11.9 \\
\text { Control } \\
7.4\end{array}$ & $\begin{array}{l}\text { The prevalence of T allele } \\
\text { was significantly higher in the } \\
\text { case group than in the control } \\
\text { group. There was a significant } \\
\text { correlation between TT } \\
\text { homozygous variant and the low } \\
\text { probability of recovery }\end{array}$ & $\begin{array}{l}\text { Ballesteros et al. } \\
(2012)[31]\end{array}$ \\
\hline Russian & $\begin{array}{l}46 \text { full-term newborns with arterial and } \\
\text { venous thrombosis, } \\
57 \text { healthy newborns as the control }\end{array}$ & $\begin{array}{l}\text { Case } \\
45.6 \\
\text { Control } \\
56.1\end{array}$ & $\begin{array}{l}\text { Case } \\
32.6 \\
\text { Control } \\
42.1\end{array}$ & $\begin{array}{l}\text { Case } \\
21.8 \\
\text { Control } \\
1.8\end{array}$ & $\begin{array}{l}\text { Together with other } \\
\text { polymorphisms, the SNPs of } \\
\text { ITGA2 C } 807 T \text { gene became a } \\
\text { criterion to identify the high-risk } \\
\text { group of arterial and venous } \\
\text { thrombosis among newborns }\end{array}$ & $\begin{array}{l}\text { Filippova et al. } \\
\text { (2020) [32] }\end{array}$ \\
\hline Russian & 446 preeclampsia patients & 32.5 & 48.4 & 19.1 & $\begin{array}{l}\text { The TT variant in ITGA2 C807T } \\
\text { gene was apparently correlated } \\
\text { with increased blood pressure } \\
\text { among women with preeclampsia } \\
\text { during the last trimester of } \\
\text { pregnancy }\end{array}$ & $\begin{array}{l}\text { Golovchenko et al. } \\
\text { (2020) [33] }\end{array}$ \\
\hline German & $\begin{array}{l}433 \text { colorectal cancer patients } \\
433 \text { healthy subjects as the control }\end{array}$ & $\begin{array}{l}\text { Patient } \\
40.6 \\
\text { Control } \\
32.9\end{array}$ & $\begin{array}{l}\text { Patient } \\
45.6 \\
\text { Control } \\
48.8\end{array}$ & $\begin{array}{l}\text { Patient } \\
13.8 \\
\text { Control } \\
18.3\end{array}$ & $\begin{array}{l}\text { The ITGA2 C } 807 \text { T polymorphism } \\
\text { was associated with a reduced } \\
\text { risk of colorectal cancer. In the } \\
\text { codominant model, the odds ratio } \\
\text { of } 807-\mathrm{T} \text { allele was } 0.77 \text {. }\end{array}$ & $\begin{array}{l}\text { Gerger et al. (2009) } \\
\text { [34] }\end{array}$ \\
\hline Malaysian & $\begin{array}{l}300 \text { patients with nasopharyngeal } \\
\text { carcinoma (NPC) }\end{array}$ & 57.0 & 34.3 & 8.7 & $\begin{array}{l}\text { The TT genotype in ITGA2 C807T } \\
\text { gene has worse all-cause survival } \\
\text { compared to the CC genotype. } \\
\text { The polymorphism could serve as } \\
\text { a biomarker of NPC prognosis. }\end{array}$ & Ban et al. (2018) [35] \\
\hline Greece & $\begin{array}{l}32 \text { fetuses with fetal growth restriction } \\
\text { (FGR) and the mothers } \\
18 \text { fetuses as the control at corresponding } \\
\text { gestational age and the mothers }\end{array}$ & $\begin{array}{l}\text { FGR } \\
46.9 \\
\text { Control } \\
50.0 \\
\end{array}$ & $\begin{array}{l}\text { FGR } \\
43.7 \\
\text { Control } \\
50.0 \\
\end{array}$ & $\begin{array}{l}\text { FGR } \\
9.4 \\
\text { Control } \\
0 \\
\end{array}$ & $\begin{array}{l}\text { There was no correlation between } \\
\text { SNPs of ITGA2 C807T and FGR }\end{array}$ & $\begin{array}{l}\text { Simou et al. (2017) } \\
\text { [36] }\end{array}$ \\
\hline
\end{tabular}


Table 2: (Continued)

\begin{tabular}{|c|c|c|c|c|}
\hline \multirow{2}{*}{$\begin{array}{l}\text { Population/ } \\
\text { Race }\end{array}$} & \multirow[t]{2}{*}{ Number of samples } & Genotype frequency (\%) & \multirow[t]{2}{*}{ Finding } & \multirow[t]{2}{*}{ References } \\
\hline & & CT & & \\
\hline \multicolumn{5}{|c|}{ Systematic review/meta-analysis } \\
\hline Category & & Subjects & Findings & Reference \\
\hline $\begin{array}{l}\text { Meta-analys } \\
\text { studies in As }\end{array}$ & $\begin{array}{l}\text { of } 15 \text { studies with a case-control design or cohort design consisting of } 11 \\
\text { race and four studies involving Caucasians }\end{array}$ & 2242 case and 2408 control & $\begin{array}{l}\text { There was a relationship between } \\
\text { ITGA2 C } 807 \mathrm{~T} \text { polymorphism } \\
\text { and the risk of ischemic stroke } \\
\text { in all Asian population and } \\
\text { hospital-based population, but not } \\
\text { in the Caucasian population and } \\
\text { non-hospitalized individuals. }\end{array}$ & Wu et al. (2014) [9] \\
\hline Meta-analys & of 16 studies with case-control, nested case-control, or cohort designs & $\begin{array}{l}2586 \text { case and } 2698 \text { control with } 16 \\
\text { studies in Asian race and Caucasians }\end{array}$ & $\begin{array}{l}\text { Together with the other two } \\
\text { polymorphisms, the TT genotype } \\
\text { or T allele in GPla C807T was } \\
\text { correlated with the increased risk } \\
\text { of ischemic stroke. }\end{array}$ & Liu et al. (2017) [11] \\
\hline $\begin{array}{l}\text { Meta-analys } \\
\text { designs }\end{array}$ & of seven studies with case-control, nested case-control, or cohort & $\begin{array}{l}209 \text { patients receiving aspirin and } \\
676 \text { control }\end{array}$ & $\begin{array}{l}\text { The ITGA2 rs } 1126643 \text { SNPs } \\
\text { indicated a significant correlation } \\
\text { with aspirin insensitivity. The } \\
\text { subgroup analysis showed that } \\
\text { these SNPs were potentially } \\
\text { higher among patients with } \\
\text { semi-resistance aspirin than in } \\
\text { the aspirin resistance group }\end{array}$ & $\begin{array}{l}\text { Weng et al. (2013) } \\
\text { [8] }\end{array}$ \\
\hline
\end{tabular}

risk of some events, including ischemic stroke, aspirin insensitivity, vein thromboembolism, recurrent attacks of $\mathrm{MI}$, and bleeding. In contrast to the three meta analyses, which draw relatively similar conclusion that SNPs are associated with the incidence of ischemic stroke and aspirin insensitivity, another meta-analysis conducted before 2010 shows that such polymorphisms are not a risk factor, either alone or in combination with other major cardiovascular risk factors, of the incidence of coronary artery disease [37]. It is interesting that nearly all of the studies linking ITGA2 rs1126643 C>T to clinical conditions other than cerebrocardiovascular disease have found significant correlations, including those associated with some types of cancer.

It is acknowledged that the ITGA gene or popularly known as integrin $\alpha 2 \beta 1$ is widely expressed in the cells associated with both the basement membrane (keratinocytes, epithelial cells, and endothelial cells) and the interstitial Collagen-I-rich matrix, such as fibroblasts, $T$ cells, myeloid cells, and megakaryocytes and/or platelets. In fact, ITGA is the only collagen-binding integrin which is expressed on platelets, thus leading to a careful definition of its important role in platelet function and homeostasis [38]. The ITGA2 gene encodes GPla, a receptor with high affinity for platelet activation, by triggering adhesion thus causing polymorphisms in the ITGA2 gene to be able to affect the risk of thrombosis as shown by the studies in Table 2. In addition, ITGA2 C807T SNPs have also proved to be associated with susceptibility to cancer and its prognosis. Therefore, the significant role of ITGA2 in various diseases, including cancer, indicates its potential to become a novel therapeutic target [39].

The high frequency of mutant allele in ITGA2 C807T (>30\%) among the Java-Indonesia population in this study requires further research along with the efforts to reduce the incidence of cardiovascular disease and the risk of cancer through health promotion strategies for cancer prevention in groups of patients with high susceptibility.

\section{Conclusion}

The allele frequency in the ITGA2 C807T gene found among the healthy Javanese-Indonesian subjects in this study is a novelty. The findings reveal that the frequency of the T allele in the ITGA2 C807T gene is lower than that of the $\mathrm{C}$ allele, which is $33.5 \%$. Further research is necessary to analyze the correlation between such polymorphisms and their implications for the pharmacodynamic variability of aspirin as well as the risk and the prognosis of some cancer types.

\section{References}

1. Goodman T, Ferro A, Sharma P. Pharmacogenetics of aspirin resistance: A comprehensive systematic review. $\mathrm{Br} J$ Clin Pharmacol 2008;66(2):222-32. https://doi. org/10.1111/j.1365-2125.2008.03183.x

PMid:18429969

2. Ittaman SV, VanWormer JJ, Rezkalla SH. The role of aspirin in the prevention of cardiovascular disease. Clin Med Res. 2014;12(3-4):147-54. https://doi.org/10.3121/cmr.2013.1197 PMid:24573704

3. Grinstein J, Cannon CP. Aspirin resistance: Current status and role of tailored therapy. Clin Cardiol. 2012;35(11):673-80. https://doi.org/10.1002/clc.22031

PMid:22740110

4. FitzGerald R, Pirmohamed M. Aspirin resistance: Effect of clinical, biochemical and genetic factors. Pharmacol Ther. 2011;130(2):213-25. https://doi.org/10.1016/j. pharmthera.2011.01.011 PMid:21295071

5. Krasopoulos G, Brister SJ, Beattie WS, Buchanan MR. Aspirin "resistance" and risk of cardiovascular morbidity: Systematic review and meta-analysis. BMJ. 2008;336(7637):195-8. https://doi.org/10.1136/bmj.39430.529549.BE

PMid:18202034 
6. Floyd $\mathrm{CN}$, Ferro A. Mechanisms of aspirin resistance. Pharmacol Ther. 2014;141(1):69-78. https://doi.org/10.1016/j. pharmthera.2013.08.005 PMid:23993980

7. Wang $\mathrm{H}$, Sun $\mathrm{X}$, Dong $\mathrm{W}$, Cai $\mathrm{X}$, Zhou $\mathrm{Y}$, Zhang $\mathrm{Y}$, et al Association of GPla and COX-2 gene polymorphism with aspirin resistance. J Clin Lab Anal. 2018;32(4):e22331. https://doi.org/10.1002/jcla.22331

PMid:28948649

8. Weng Z, Li X, Li Y, Lin J, Peng F, Niu W. The association of four common polymorphisms from four candidate genes (COX1, COX-2, ITGA2B, ITGA2) with aspirin insensitivity: A metaanalysis. PLoS One. 2013;8:e78093.

PMid:24244288

9. Wu G, Xi Y, Yao L, Su L, Yan Y, Li M, et al. Genetic polymorphism of ITGA2 C807T can increase the risk of ischemic stroke. Int $J$ Neurosci 2014;124(11):841-51. https://doi.org/10.3109/002074 54.2013 .879718

PMid:24397542

10. Lu JX, Lu ZQ, Zhang S, Zhi J, Chen ZP, Wang WX. Polymorphism in integrin ITGA2 is associated with ischemic stroke and altered serum cholesterol in Chinese individuals. Balkan Med J. 2014;31(1):55-9. https://doi.org/10.5152/balkanmedj.2013.7993 PMid:25207168

11. Liu H, Wang Y, Zheng J, Li G, Chen T, Lei J, et al. Platelet glycoprotein gene la C807T, HPA-3, and lb $\alpha$ VNTR polymorphisms are associated with increased ischemic stroke risk: Evidence from a comprehensive meta-analysis. Int J Stroke. 2017;12:46-70. https://doi.org/10.1177/1747493016672085 PMid:28004990

12. Holsinger KE. Hardy-Weinberg Law. Encyclopedia of Genetics. Amsterdam, Netherlands: Elsevier; 2001. p. 912-4. https://doi. org/10.1006/rwgn.2001.0585

13. Rogers AJ, Weiss ST. Epidemiologic and population genetic studies. In: Clinical and Translational Science. Amsterdam, Netherlands: Elsevier; 2017. p. 313-26. https://doi.org/10.1016/ B978-0-12-802101-9.00017-X

14. Faraday N, Goldschmidt-Clermont PJ, Bray PF. Gender differences in platelet GPIIb-IIla activation. Thromb Haemost. 1997;77(4):748-54 PMid:9134654

15. Berger JS, Roncaglioni MC, Avanzini F, Pangrazzi I, Tognoni G, Brown DL. Aspirin for the primary prevention of cardiovascular events in women and men: A sex-specific meta-analysis of randomized controlled trials. JAMA. 2006;295(3):306-13. https://doi.org/10.1001/jama.295.3.306

PMid:16418466

16. Ridker PM, Cook NR, Lee IM, Gordon D, Gaziano JM, Manson JE, et al. A randomized trial of low-dose aspirin in the primary prevention of cardiovascular disease in women. N Engl J Med. 2005;352(13):1293-304. https://doi.org/10.1056/ NEJMoa050613

PMid:15753114

17. Franconi F, Campesi I. Pharmacogenomics, pharmacokinetics and pharmacodynamics: Interaction with biological differences between men and women. Br J Pharmacol. 2014;171(3):580-94. https://doi.org/10.1111/bph.12362

PMid:23981051

18. Kvasnicka T, Bobcikova P, Malikova I, Hajkova J, Zima T, Ulrych $\mathrm{J}$, et al. The frequencies of ten platelet polymorphisms associated with atherosclerotic cardiovascular disease in patients with venous thromboembolism: A population-based case-control study. Hereditary Genet. 2015;4:153. https://doi. org/10.4172/2161-1041.1000153

19. Zhang JH, Wang J, Tang XF, Yao Y, Zhang Y, Ma YL, et al.
Effect of platelet receptor gene polymorphisms on outcomes in ST-elevation myocardial infarction patients after percutaneous coronary intervention. Platelets. 2016;27(1):75-9. https://doi.org /10.3109/09537104.2015.1034096

PMid:25901734

20. Al-Azzam SI, Alzoubi KH, Khabour OF, Tawalbeh D, Al-Azzeh O. The contribution of platelet glycoproteins (GPla C807T and GPIba C-5T) and cyclooxygenase 2 (COX-2G-765C) polymorphisms to platelet response in patients treated with aspirin. Gene. 2013;526(2):118-21. https://doi.org/10.1016/j. gene.2013.04.083

PMid:23688555

21. Liakhotska A. Genetic features of resistance to antithrombocytic drugs in patients with ischemic heart disease after conducted percutaneous coronary intervention. EUREKA. 2017;6:35-41. https://doi.org/10.21303/2504-5679.2017.00490

22. Cole VJ, Staton JM, Eikelboom JW, Hankey GJ, Yi Q, Shen $\mathrm{Y}$, et al. Collagen platelet receptor polymorphisms integrin $\alpha 2 \beta 1$ C807T and GPVI Q317L and risk of ischemic stroke. J Thromb Haemostasis. 2003;1(5):963-70. https://doi. org/10.1046/j.1538-7836.2003.00179.x

PMid: 12871362

23. Rath D, Schaeffeler E, Winter S, Levertov S, Müller K, Droppa M, et al. GPla polymorphisms are associated with outcomes in patients at high cardiovascular risk. Front Cardiovasc Med. 2017;4:52. https://doi.org/10.3389/fcvm.2017.00052 PMid:28871283

24. Martínez C, Antón Al, Corral J, Quiroga T, Panes O, Lozano ML, et al. Genotype-phenotype relationship for six common polymorphisms in genes affecting platelet function from 286 healthy subjects and 160 patients with mucocutaneous bleeding of unknown cause. Br J Haematol. 2009;146(1):95-103. https:// doi.org/10.1111/j.1365-2141.2009.07713.x

PMid:19388931

25. Verschuren JJW, Boden $\mathrm{H}$, Wessels JA, van der Hoeven BL, TrompetS, Heijmans BT, etal. Value of platelet pharmacogenetics in common clinical practice of patients with ST-segment elevation myocardial infarction. Int J Cardiol. 2013;167(6):28828. https://doi.org/10.1016/j.ijcard.2012.07.020 PMid:22940005

26. Liu H, Xu Z, Gu H, Li W, Chen W, Sun C, et al. Common variant in glycoprotein ia increases long-term adverse events risk after coronary artery bypass graft surgery. J Am Heart Assoc. 2016;5(12):e004496. https://doi.org/10.1161/JAHA.116.004496 PMid:27881421

27. Sionova M, Blasko P, Jirous S, Vindis D, Rokyta R, Motovska Z. Association of polymorphisms of platelet receptors GPla (807C>T), GPVI (13254T>C), and P2Y12 (34C>T and H1/ $\mathrm{H} 2$ haplotype) with increased risk of periprocedural bleeding in patients undergoing coronary angiography/percutaneous coronary intervention. Postepy Kardiol Interwencyjnej. 2017;13(3):202-9. https://doi.org/10.5114/aic.2017.70187 PMid:29056992

28. Mukarram O, Akhtar N, Junaid A, Mohyuddin A. A study into the genetic basis of aspirin resistance in Pakistani patients with coronary artery disease. Pak J Pharm Sci. 2016;29(4):1177-82. PMid:27393450

29. Fujiwara T, Ikeda M, Esumi K, Fujita TD, Kono M, Tokushige H, et al. Exploratory aspirin resistance trial in healthy Japanese volunteers (J-ART) using platelet aggregation as a measure of thrombogenicity. Pharmacogenomics J. 2007;7(6):395-403. https://doi.org/10.1038/sj.tpj.6500435 PMid:17245331

30. Chen J, Liu NN, Li JQ, Yang L, Zeng Y, Zhao XM, et al. Association between ITGA2 C807T polymorphism and gastric 
cancer risk. World J Gastroenterol. 2011;17(23):2860-6. https:// doi.org/10.3748/wjg.v17.i23.2860

PMid:21734795

31. Ballesteros F, Tassies D, Reverter JC, Alobid I, Bernal-Sprekelsen M. Idiopathic sudden sensorineural hearing loss: Classic Cardiovascular and new genetic risk factors. Audiol Neurootol. 2012;17(6):400-8. https://doi. org/10.1159/000341989

PMid:22948415

32. Filippova OA, Vakhlova IV, Tsaur GA, Kuznetsov NN Abolina TB. The role of thrombophilia genes in the clinical implementation of arterial and venous thrombosis in newborns. BIO Web Conf. 2020;22:02021. https://doi.org/10.1051/ bioconf/20202202021.

33. Golovchenko OV, Abramova MY, Altukhova OB, Verzilina IN Rudyh NA, Kulikovsky VF. The role of polymorphism of hereditarythrombophilia candidate genes in the development of arterial hypertension in women with preeclampsia. Syst Rev Pharm. 2020;11(6):11-5.

34. Gerger A, Hofmann G, Langsenlehner U, Renner W, Weitzer W, Wehrschütz $\mathrm{M}$, et al. Integrin alpha-2 and beta-3 gene polymorphisms and colorectal cancer risk. Int J Colorectal Dis. 2009;24(2):159-63. https://doi.org/10.1007/s00384-008-0587-9 PMid: 18836731

35. Ban EZ, Lye MS, Chong PP, Yap YY, Lim SY, Rahman HA.
Association of hOGG1 Ser326Cys, ITGA2 C807T, TNF-A -308G $>$ A and XPD Lys751GIn polymorphisms with the survival of Malaysian NPC patients. PLoS One. 2018;13(6):e0198332. https://doi.org/10.1371/journal. pone.0198332

36. Simou M, Kouskouni E, Vitoratos N, Economou E, Creatsas G. Polymorphisms of platelet glycoprotein receptors and cell adhesion molecules in fetuses with fetal growth restriction and their mothers as detected with pyrosequencing. In Vivo. 2017;31(2):243-9. https://doi.org/10.21873/invivo.11052 PMid:28358707

37. Tsantes AE, Nikolopoulos GK, Bagos PG, Vaiopoulos G Travlou A. Lack of association between the platelet glycoprotein la C807T gene polymorphism and coronary artery disease: A meta-analysis. Int J Cardiol. 2007;118(2):189-96. https://doi. org/10.1016/j.ijcard.2006.06.047

PMid:17023078

38. Madamanchi A, Santoro SA, Zutter MM. $\alpha 2 \beta 1$ integrin. Adv Exp Med Biol. 2014;819:41-60. https://doi. org/10.1007/978-94-017-9153-3_3

PMid:25023166

39. Adorno-Cruz $\mathrm{V}$, Liu $\mathrm{H}$. Regulation and functions of integrin $\alpha 2$ in cell adhesion and disease. Genes Dis. 2018;6(1):16-24. https:// doi.org/10.1016/j.gendis.2018.12.003

PMid:30906828 